mgr inz. Szymon Finke

dr hab. inz. Tadeusz Piechowiak prof. PP

Politechnika Poznańska

mgr inz. Karol Bryk

mgr inz. Adam Sienicki

Instytut Pojazdów Szynowych „TABOR”

\title{
Proposal to modify the wheel profile of Poznan Fast Tram
}

\begin{abstract}
PFT tram wheel profile is considered the standard profile in Poland. Despite its modern design this profile, in combination with the most commonly used rail profiles in Poland it may lead to instability, even at regular operating speeds. Although the relationship between $Y / Q$ forces is not at a dangerous level in these cases, it leads to the increase in wheels and rails wear and the deterioration of the tram operating properties.

The influence of selected, possibly small PFT profile modifications, was analyzed. These modifications were made to increase the stability on a variety of rails, an analysis of these modifications on the hypothetical process of wear of wheel/rail parts was also performed.
\end{abstract}

\section{Propozycja modyfikacji profilu koła tramwajowego Poznańskiego Szybkiego Tramwaju}

\begin{abstract}
Profil koła tramwajowego typu PST jest profilem objętym normq obowiqzujqca w Polsce. Pomimo nowoczesności tego profilu, w skojarzeniu ze stosownymi często w Polsce profilami szyn może on wykazywać niestabilność nawet przy eksploatacyjnych prędkościach jazdy. Pomimo, ze nie występuje $w$ tych przypadkach niebezpieczny poziom stosunku sit $Y / Q$, to wplywa to na zwiększenie zużycia kót i szyn oraz na pogorszenie właściwości biegowych tramwajów.

Zanalizowano wpływ wybranych, możliwie małych modyfikacji profilu PST, dokonanych $w$ celu zwiększenia stabilności na różnych szynach, dokonano również analizy tych modyfikacji na hipotetyczny proces zużywania elementów koło-szyna.
\end{abstract}

\section{Charakterystyka profilu PST}

Profil koła tramwajowego typu PST jest profilem utworzonym w połowie lat 80-tych XX wieku w Instytucie Pojazdów Szynowych „Tabor” w Poznaniu [1], pierwotnie na potrzeby nowo budowanej linii tramwajowej Poznańskiego Szybkiego Tramwaju i został w 1991 roku przyjęty jako profil objęty polską normą PN-91 K-88251 z 1992 r. oraz nieco później w PN-K92016 wprowadzonej w 1997 r. do obowiązkowego stosowania $\mathrm{w}$ taborze tramwajowym.

W tej późniejszej normie podano, że stosowanie innego konturu bieżni jest dopuszczalne, jeżeli zachowany jest wymiar kontrolny szerokości obrzeża i średnica zewnętrzna koła. Profil ten jest powszechnie stosowany w większości taboru tramwajowego w Polsce (rys. $1)$.

W normie z 1992 [2] i 1997 [3] w profilu PST istnieją różne promienie łuku przejściowego i $\mathrm{W}$ PN-91 K88251 wynosi on $80 \mathrm{~mm}$, a w PN-K-92016 wynosi 90 $\mathrm{mm}$.

\section{PFT profile characteristics}

PFT type wheel profile is a profile created in the mid80 s of the twentieth century at the Rail Vehicles Institute "Tabor" in Poznan [1]. Initially developed for the newly built Poznan Fast Tram line the profile was adopted in 1991 as the Polish norm PN-91 K-88251 from 1992, and later in the PN-K-92016 introduced in 1997 as compulsory wheel profile for tramrolling stock.

That last norm stated that the use of different track contour is permitted, provided the original control dimension of the edge width and the wheel outer diameter is retained. This profile is now commonly used in the majority of trams in Poland (Fig. 1).

The norms introduced in 1992 [2] and in 1997 [3] have different track transition radii in the PFT profile and it equals $80 \mathrm{~mm}$ in the PN-91 K-88251, and $90 \mathrm{~mm}$ in the PN-K-92016. 
Do modyfikacji tego profilu przyjęto ten wg nowszej normy, z promieniem $90 \mathrm{~mm}$. Profil PST jest korzystny również dla taboru z kołami niezależnymi, gdyż posiada pożądaną cechę, jaką jest kształt krzywoliniowy (kołowy) na znacznej części roboczej, co daje siłę centrująca geometryczną (pochodzącą od sił grawitacyjnych), jedyną występującą w kołach niezależnych. W dalszych latach po wprowadzeniu tego profilu stwierdzono, przy wykorzystaniu współczesnych narzędzi analiz zużycia profili, obok niewątpliwych zalet tego profilu stwierdzono pewną jego nieoptymalność.

Profil koła PST charakteryzuje się umiarkowanie dobrą współpracą z nową szyną rowkową $60 \mathrm{R} 2$, ale gorszą z nową szyną S49 o pochyleniu 1:40. Podczas ruchu zestawy kołowe doznają wężykowania, dla obu wymienionych profili szyn punkty styku kół z szynami przemieszczają się w zbyt wąskim zakresie, co będzie skutkowało silnym strefowym zużyciem (ściernym i zmęczeniowym) obydwu profili. Ekwiwalentna stożkowatość na szynie 60R2 dla nominalnego prześwitu toru $1435 \mathrm{~mm}$ jest $\mathrm{w}$ prawidłowym zakresie $0.13 \div 0.29$, natomiast na szynie S49 jest $\mathrm{w}$ zakresie nieprawidłowym, $\mathrm{z}$ dużymi wartościami $\mathrm{w}$ zakresie $0.32 \div 0.50$.

Profil PST w strefie położonej najbardziej na zewnątrz koła daje styk między nowymi profilami koła i szyny (rozpatrywano szczegółowiej występujący na torach tramwajowych profil koła R49 1:40 lub 60R2 z wbudowanym pochyleniem 1:40), o kącie pochylania powierzchni styku bardzo zbliżonym do poziomu. Powoduje to brak centrowania kół pojazdu (zarówno brak centrowania kinematycznego, jak i geometrycznego). W strefie tej dla wymienionych profili szyn z profilem PST następuje na torze prostym najczęstszy styk i tego należałoby uniknąć.

Z kolei dla skojarzenia profilu PST z profilem 60R2 przy rozstawie szyn $1435 \mathrm{~mm}$ następuje duży przeskok punktu styku determinując dużą stożkowatość mimo niewielkiego nachylenia tego punktu styku $\dot{i}$ a to powoduje skłonność pojazdów do niestabilności. Dla profilu S49 taki przeskok następuje już przy rozstawie $1430 \mathrm{~mm}$, a poczynając od około $2 \mathrm{~mm}$ przesunięcia koła względem szyny następuje dosyć gwałtowny wzrost stożkowatości do wartości ponad 0,5. Dopiero w dalszym zakresie przesuwów poprzecznych kół następuje chwilowy jej spadek do wartości ok. 0,4. Ekwiwalentną stożkowatość profilu PST skojarzonego z szyną $60 \mathrm{R} 2$ przedstawiono na rys. 2 , a z szyną $\mathrm{S} 49$ 1:40 na rys. 3 .

Na rysunkach 4 i 5 przedstawiono rozkład punktów styku dla obu omawianych profili szyn.

W przypadku styku z szynami S49, punkty styku będą wywoływały bardzo małą stożkowatość $\mathrm{w}$ położeniu środkowym kół, przy nieco ich większych przesunięciach poprzecznych, z powodu gwałtownie wzrastającej stożkowatości koła, będą z dużą siłą zawracane do zakresu bardzo małych stożkowatości, gdzie mogą

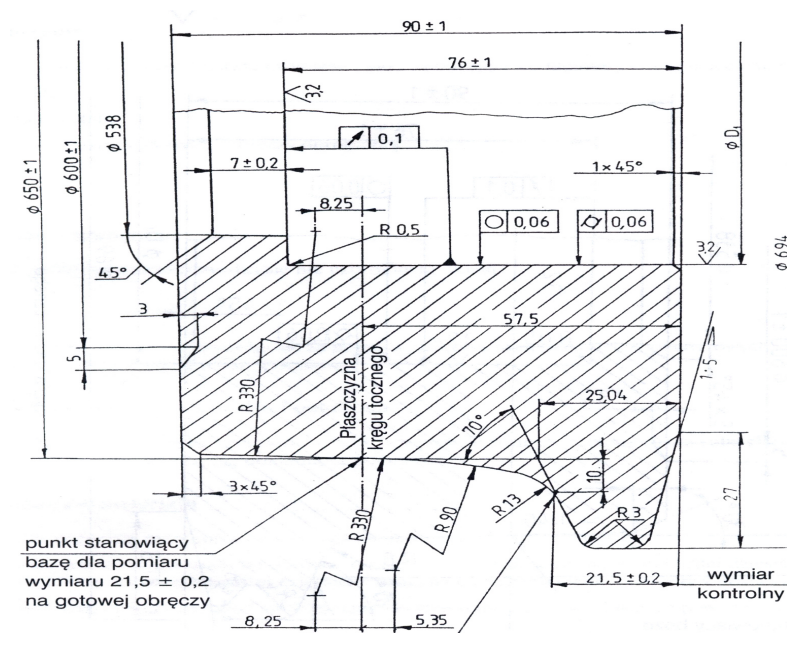

Rys. 1. Fragment profilu PST wg normy PN-K-92016

Fig. 1. PFT wheel profile fragment as described in PN-K-92016

Profile modification used the new profile norm, with a radius of $90 \mathrm{~mm}$. The PFT profile is beneficial also for rolling stock with independent wheels, because it has a desirable trait, namely a curved shape (circular) on most of the contact surface, which provides centering geometric force (derived from the gravitational forces), which only occurs in independent wheels. Within a few years after the introduction of this wheel profile it was found, using modern profile wear analysis tools, that in addition to the undoubted advantages of this profile some lack of optimization was discovered.

PFT wheel profile is characterized by a moderately good cooperation with the new grooved rail 60R2, but worse with the new S49 rail with 1:40 inclination. During movement the wheel sets experience sway. In both of the rail profiles the wheel/rail contact points move in too narrow a range, which results in a strong local wear (abrasive and fatigue) of both profiles. The equivalent conicity of the 60R2 rail for the nominal track gauge of $1435 \mathrm{~mm}$ is in the acceptable range of $0.13 \div 0.29$, while for the rail $\mathrm{S} 49$ its value is in a range of large values between $0.32 \div 0.50$.

PFT profile in the parts of the outermost circle provides contact between the new wheel and rail profiles (the R49 wheel profile 1:40 or the 60R2 with a tilt of 1:40 were considered in more detail), where the contact surfaces were nearly lateral. It causes lack of centring of the vehicle wheels (neither kinematic nor geometric). The most frequent contact in this outermost circle takes place on the straight track, for the mentioned rail profiles with the PFT profile, which should be avoided.

In turn, the interaction between PFT profile and 60R2 profile at the gauge of $1435 \mathrm{~mm}$ leads to a big jump in the point of contact thus causing a large conicity, despite the small inclination of the point of contact which leads to vehicle instability. For the S49 profile transition already occurs at track gauge of $1430 \mathrm{~mm}$, 
przyjmować dosyć dowolne pozycje, gdy są niejako odbijane od dużej stożkowatości.

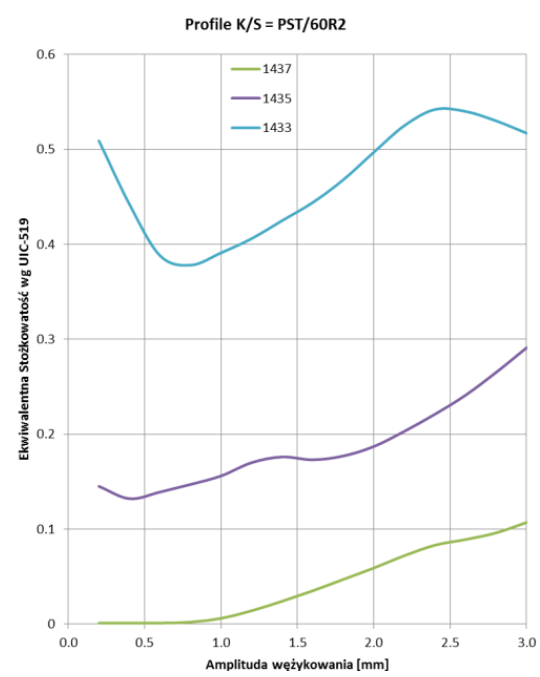

Rys. 2 Stożkowatość ekwiwalentna profilu PST - 60R2

Fig. 2 Equivalent conicity of the PFT - 60R2 profile

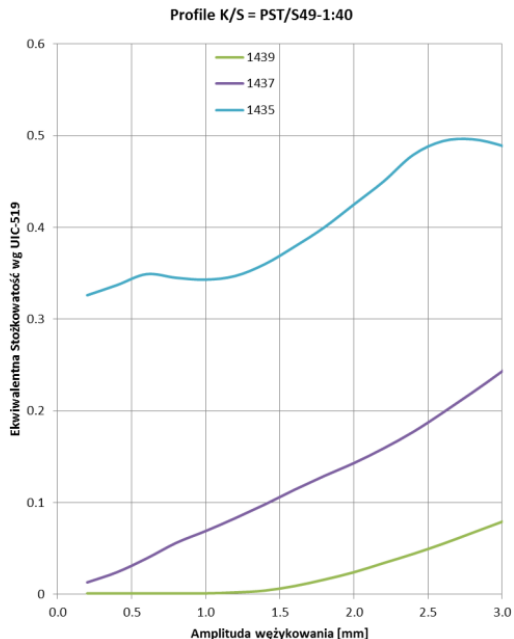

Rys. 3. Stożkowatość ekwiwalentna profilu PST - S49 1:40

Fig. 3. Equivalent conicity of the PFT - S49 1:40 profile

$\mathrm{Na}$ rys.6 przedstawiono przebieg zachowania się zestawu kołowego przy jeździe ze zmienną prędkością i początkowym wymuszeniu poprzecznym. Zjawisko to jest bardzo podobne do klasycznej niestabilności pojazdu, ale w małym stopniu wywołane siłami bezwładności w kierunku poprzecznym. Z tego powodu amplituda jest prawie niezależna od prędkości jazdy i tym samym mało niebezpieczna.

Analiz stabilności tramwaju z rozpatrywanymi profilami dokonano programem SIMPACK wzbudzając zestawy kołowe początkowym wzbudzeniem poprzecznym przy maksymalnej prędkości jazdy i zmniejszając stopniowo tą prędkość. Stabilność analizowano do $80 \mathrm{~km} / \mathrm{h}$ (ok. $10 \%$ więcej, niż prędkość maksymalna $70 \mathrm{~km} / \mathrm{h}$ ).

Na rys. 6 przedstawiono stabilność dla profilu starszego $\mathrm{z}$ łukiem przejściowym $\mathrm{r}=80 \mathrm{~mm}$. and starting from about $2 \mathrm{~mm}$ displacement of the wheel relative to the rail it takes quite a sharp increase in conicity value of above 0.5 . Only at further transverse wheel offsets it takes a momentary drop in value to approximately 0.4 . The equivalent conicity of the PFT profile associated with the rail 60R2 is shown in Fig. 2 and the rail S49 1:40 in Fig. 3.

Figures 4 and 5 show the distribution of contact points for these two rail profiles.

In the case of the S49 rails, the contact points will cause a very small conicity in the middle wheel point, with slightly greater transverse movements, due to the rapidly increasing wheel conicity they will be forcefully returned to the range with very small conicity, which may take quite arbitrary positions as they get pushed away from a large conicity.

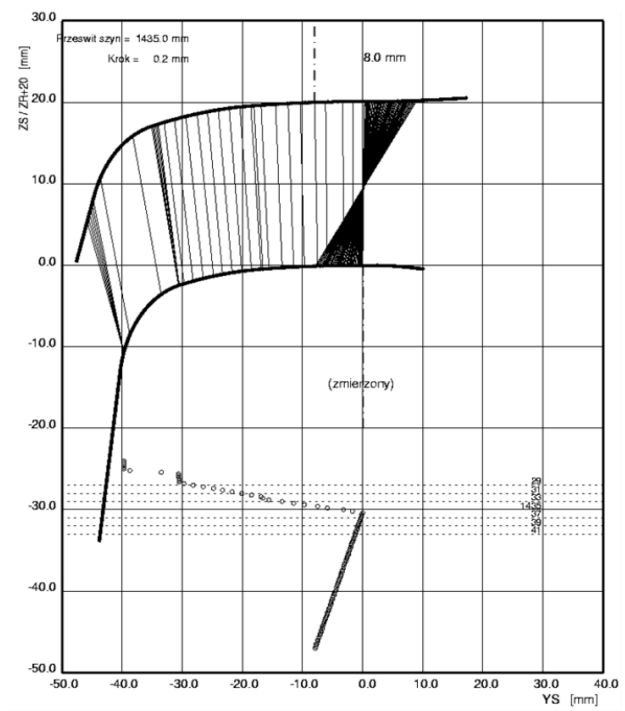

Rys. 4. Rozład punktów styku profilu PST - 60R2

Fig. 4. Contact point distribution for PFT - 60R2 profile

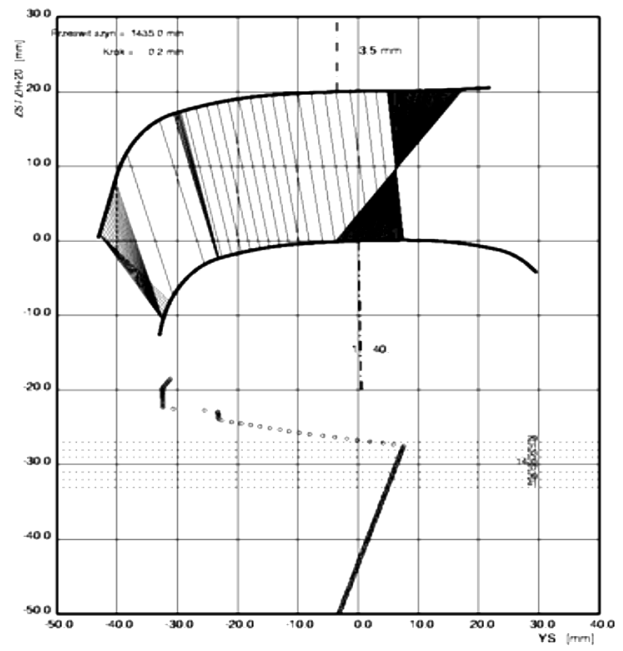

Rys. 5. Rozład punktów styku profilu PST - S49 1:40

Fig. 5. Contact point distribution for PFT - S49 1:40 profile

Figure 6 shows the behavior of the wheelset when traveling at variable speed and with initial transverse forcing. This phenomenon is very similar to classical vehicle instability, but to a small extent caused by inertial forces in the transverse direction. Hence, the 


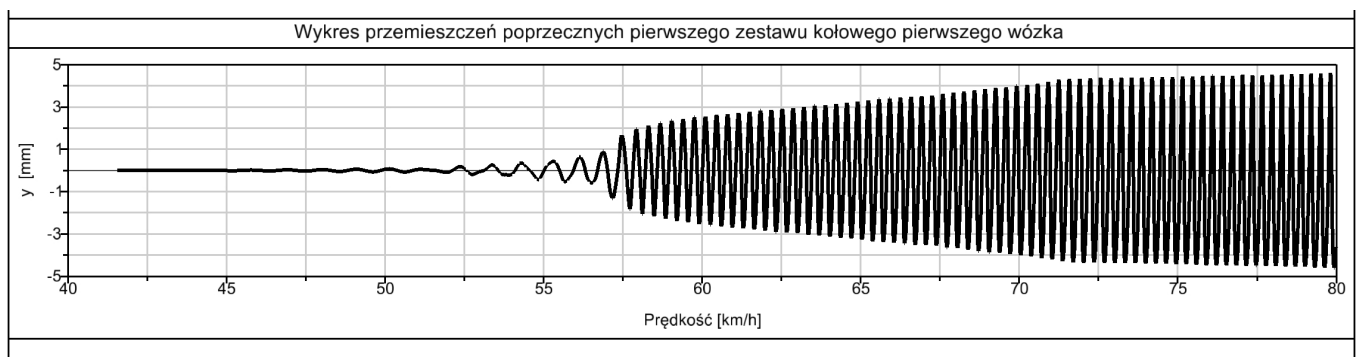

Rys. 6. Stabilność tramwaju z profilem PST z łukiem przejściowym $80 \mathrm{~mm}$ (starsza norma) i szynie S49 1:40 rozstaw $1435 \mathrm{~mm}$

Fig. 6. The stability of the tram's PFT profile for transition arc of $80 \mathrm{~mm}$ (older standard) and track S49 1:40 with gauge $1435 \mathrm{~mm}$

Nie wszystkie przedsiębiorstwa dokonały zmiany profilu wg. nowszej normy.

Pozostałe rysunki przedstawiają stabilność tramwaju z nowszym łukiem przejściowym profilu $\mathrm{r}=90 \mathrm{~mm}$.

Przy wystarczająco wielkiej początkowej amplitudzie wymuszenia wywołuje to wężykowanie w zakresie dużych prędkości oraz nadmierne tym stymulowane zużywanie par koło-szyna. Cierne zużycie eksploatacyjne koncentruje się w części środkowej profilu a w konsekwencji zmniejsza stożkowatość w czasie jazdy na torze prostym. W trakcie jazdy na łuku o umiarkowanym promieniu $\mathrm{w}$ warunkach nierówności toru również powoduje to częstszy kontakt szyny $\mathrm{z}$ obrzeżem koła lub obrzeża $\mathrm{z}$ powierzchnią wewnętrzną rowka (styk dwupunktowy), a to wywołuje większy poziom hałasu kół aż do piszczenia. amplitude is almost independent of the speed and therefore less dangerous.

Analysis of tram stability with the considered profiles was done using the SIMPACK program driving wheelsets with an initial transverse force at maximum speed and gradually reducing the speed. The stability was analyzed up to $80 \mathrm{~km} / \mathrm{h}$ (approx. $10 \%$ more than the maximum speed of $70 \mathrm{~km} / \mathrm{h}$ ).

Figure 6 shows the stability of the older profile at a transition arc $\mathrm{r}=80 \mathrm{~mm}$.

Not all companies have made changes in accordance with the newer profile standards.

Other figures show the tram stability with higher profile transition arc $\mathrm{r}=90 \mathrm{~mm}$.

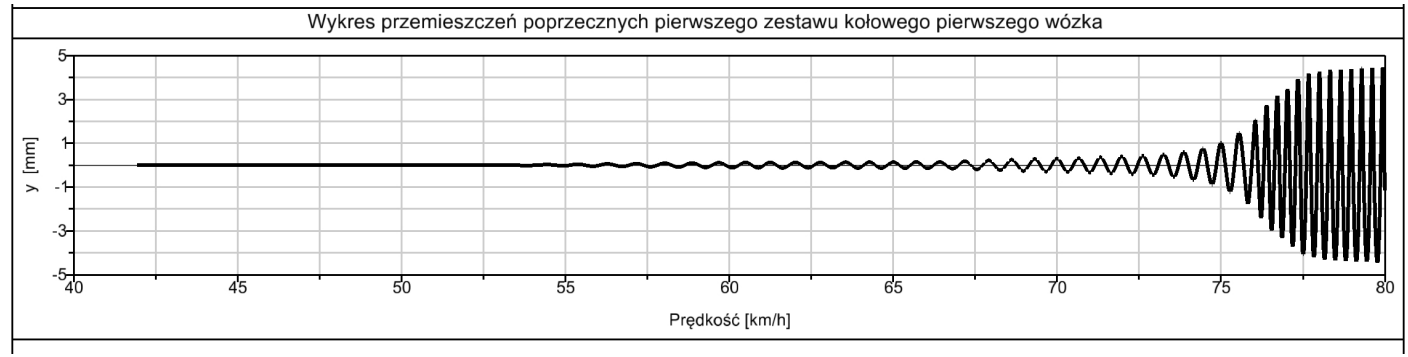

Rys. 7. Stabilność tramwaju z profilem PST z łukiem przejściowym profilu $90 \mathrm{~mm}$ (nowsza norma) i szyną 60R2 rozstaw $1435 \mathrm{~mm}$

Fig. 7. Tram stability with the PFT profile transition arc $90 \mathrm{~mm}$ (newer standard) and the trackl 60R2 and gauge $1435 \mathrm{~mm}$

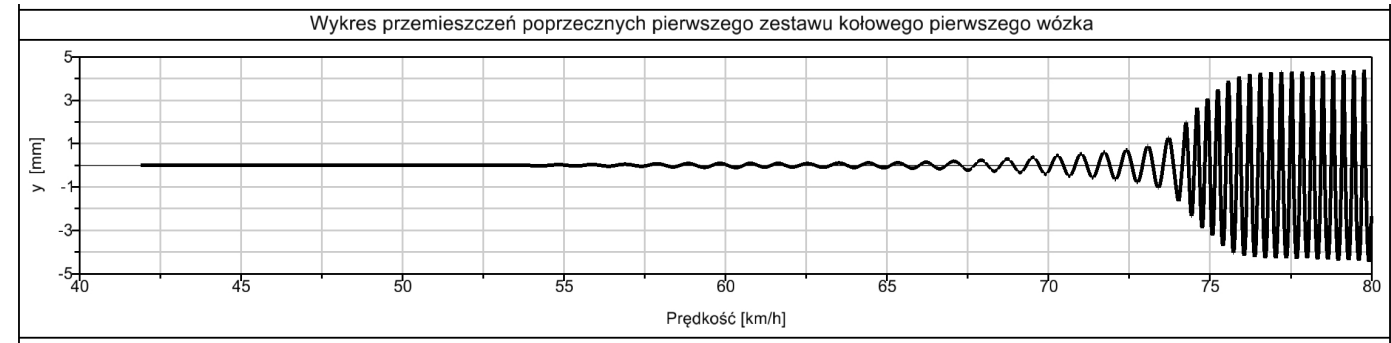

Rys. 8. Stabilność tramwaju z profilem PST i szyną S49 1:40 rozstaw $1435 \mathrm{~mm}$

Fig. 8. Tram stability with the PFT profile and track S49 1:40 with gauge $1435 \mathrm{~mm}$

\section{Modyfikacje profilu PST}

\subsection{Cel modyfikacji profilu PST}

Celem pracy jest zaproponowanie niewielkiej ( jak wyżej przedstawiono, jest to dopuszczalne norma), nie zmieniającej korzyści stosowania tego profilu w porównaniu z profilami starszymi. Dokonano analizy kilku wariantów modyfikacji wyszczególnionych poniżej:
A sufficiently large initial forcing amplitude causes a sway in the high-speed range and accelerated wear of wheels and rails. Frictional wear and tear is concentrated in the central part of the wheel profile and therefore reduces the conicity when traveling on straight track. Driving in a curve with a moderate radius and uneven track conditions also increases the contact 


\subsection{Modyfikacja A}

Modyfikacja A polega na zmianie środka promienia R330 (wypukłego) z $8.25 \mathrm{~mm}$ na $-8.25 \mathrm{~mm}$. Celem jest takie przesunięcie punktu styku promieni, by była zachowana pewna stożkowatość. Innym rozwiązaniem jest Modyfikacja As - zastapienie łuku kołowego w części zewnętrznej profilu odcinkiem prostym o stałym pochyleniu, przyjętym jako 1:20. Różnica właściwości tych wariantów nowego profilu jest niewiel$\mathrm{ka}$, ale teoretycznie profil z odcinkiem prostoliniowym winien dawać nieco większe prowadzenie kinematyczne dla kół niezależnych.

Dla tych modyfikacji profilu największe zużywanie toru i kół przesunie się nieco do wnętrza toru stabilizując umiarkowaną stożkowatość (zamiast małej) i zapewniając lepsze, bardziej równomierne prowadzenie również w łukach tramwajowych o średnim promieniu łuku. Proces częściowej zmiany sposobu zużywania się par ciernych zachodziłby również dla szyn częściowo zużytych (przed wprowadzeniem modyfikacji) powoli w trakcie eksploatacji.

Na rysunkach 9 i 10 przedstawiono propozycję częściowej modyfikacji profilu PST w zewnętrznej części profilu profilem prostym, a na rys. 11 i 12 przedstawiono uszeregowanie punktów styku i przebieg stożkowatości ze skojarzeniu z szyną nową 60R2 (rys.11) lub R49 (rys.12).

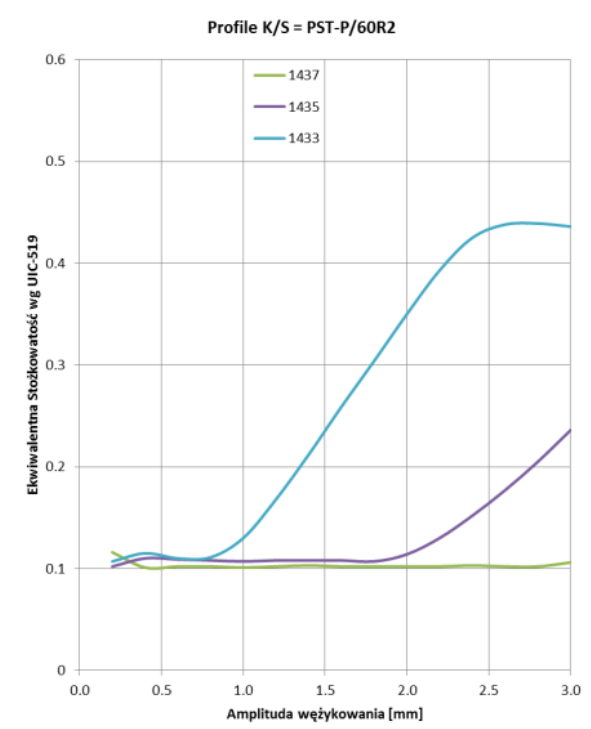

Rys. 9. Stożkowatość ekwiwalentna profilu: PST Modyfikacja A - 60R2

Fig. 9. Equivalent conicity of the PFT profile Modification

$$
\text { A - 60R2 }
$$

Wynik tych modyfikacji obejmowałby nieco większą stabilność, ale przesunięcie na szynie w tym zakresie byłoby niewielkie i zużycie szyny i było by tylko nieco mniejsze, niż dla PST.

\subsection{Modyfikacja B}

Modyfikacja $B$ polega na zmianie środków promieni R330 (wklęsłego i wypukłego) z $8.25 \mathrm{~mm}$ na $12 \mathrm{~mm}$. Wykazuje ona istotne różnice rozkładu punktów styku względem profilu podstawowego. between the rail and the wheel or the rim with the inner surface of the groove (two-point contact), leading to an increase in noise level even to the squealing.

\section{PFT profile modifications}

2.1.The goal of PFT profile modification

The objective is to propose a small change in profile (it is acceptable by the norms), without changing the benefits compared to the older profiles. The analysis of several variants of modifications is listed below:

\subsection{Modification A}

Modification A is to change the center of the R330 (convex) radius from $8.25 \mathrm{~mm}$ to $-8.25 \mathrm{~mm}$. The aim is the shift of the radii point of contact while preserving the conicity. Another solution is to modify As - replacing the circular arc part of the outer profile with a straight section of constant slope of 1:20. The difference in the properties of these new profile variants is small, but theoretically the profile of a straight section should provide a little more kinematics for independent wheels.

For these profile modifications the majority of track and wheel wear will move slightly to the inside of the track stabilizing moderate conicity (instead of low) and providing a more uniform movement in arcs with an average arc radius. The partial changes of the wear process for the friction components would also appear for partially used for rails (before modifications) gradually during operation.

Figures 9 and 10 show a proposal for a partial modification of the PFT profile outer part with a straight profile, and Figures 11 and 12 show the ordering of contact points and the conicity change from the combination of a new 60R2 rail (Figure 11) or R49 (Figure 12).

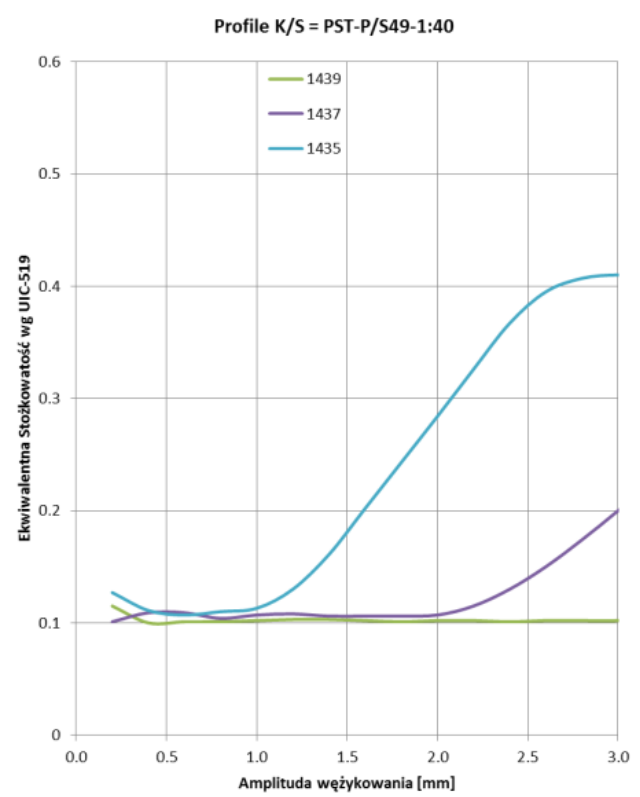

Rys. 10. Stożkowatość ekwiwalentna profilu: PST Modyfikacja A - S49 1:40

Fig. 10. Equivalent conicity of the PFT profile Modification A - S49 1:40 


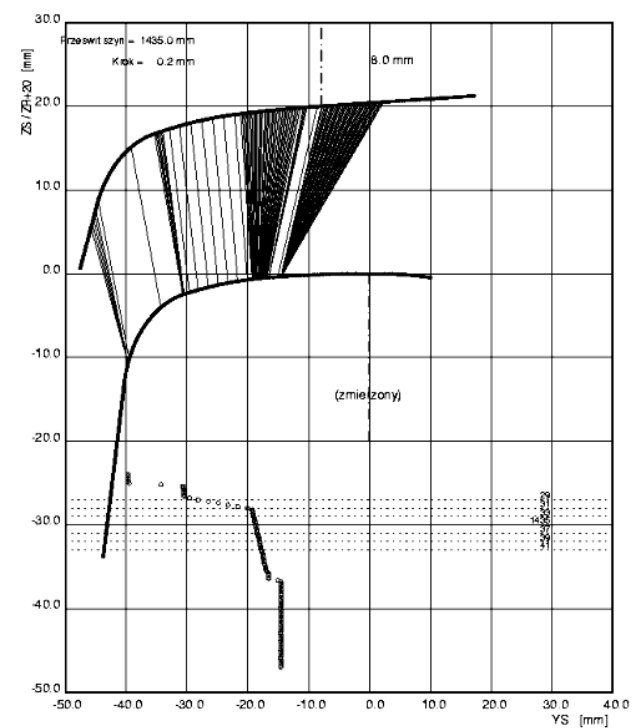

Rys. 11 . Rozkład punktów styku profilu: PST Modyfikacja A - 60R2

Fig. 11 . Contact points graph for the PFT profile Modification A - 60R2

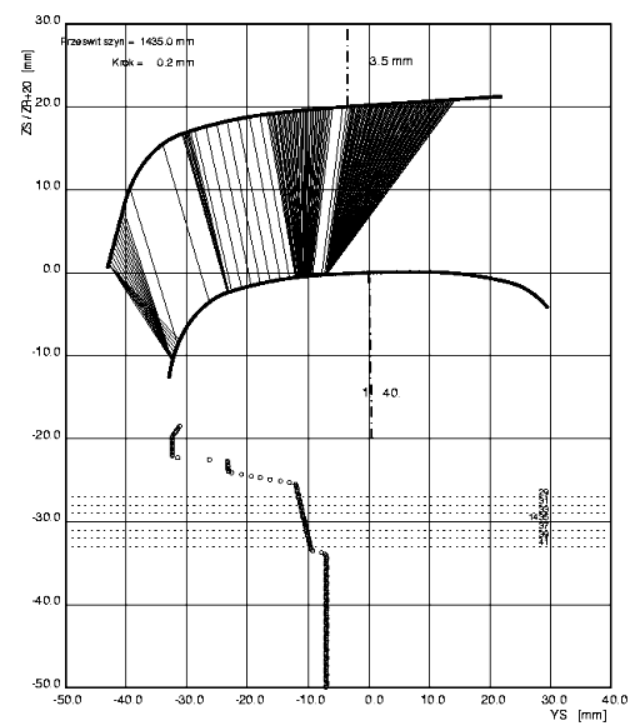

Rys. 12. Rozkład punktów styku profilu: PST Modyfikacja A - S49 1:40

Fig. 12. Contact points graph for the PFT profile Modification A - S49 1:40

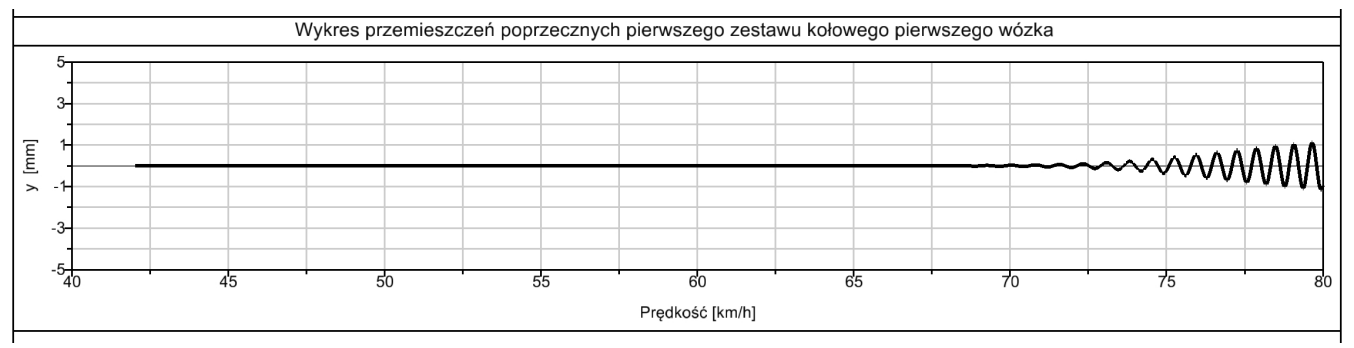

Rys. 13. Stabilność tramwaju z profilem: PST Modyfikacja A, szyna S49 1:40 rozstaw $1435 \mathrm{~mm}$

Fig. 13. Tram stability with PFT profile: Modification A, rail S49 1:40 gauge $1435 \mathrm{~mm}$

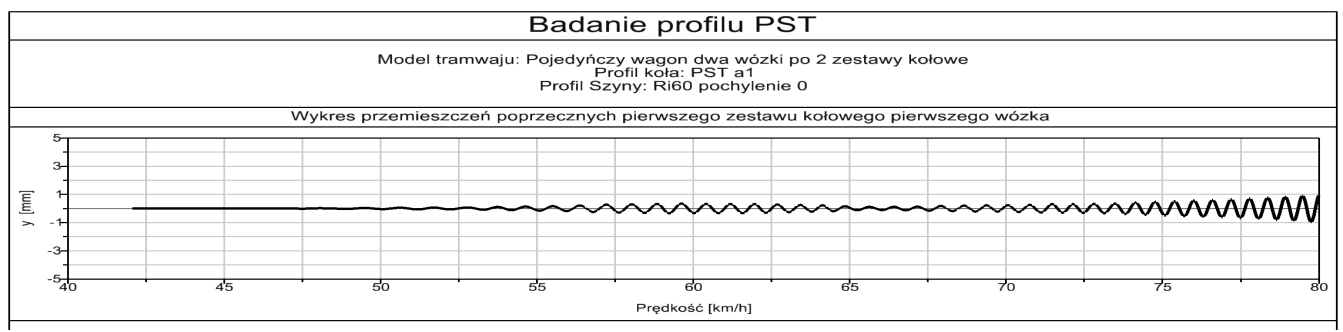

Rys. 14. Stabilność tramwaju z profilem: PST Modyfikacja A, szyna 60R2 rozstaw $1435 \mathrm{~mm}$

Fig. 14. Tram stability with PFT profile: Modification A, rail 60R2 gauge $1435 \mathrm{~mm}$

Charakteryzuje się znacznie lepszą współpracą z nową szyna rowkowa 60R2 i dobra z nową szyną S49 o pochyleniu 1:40. Gdyby wystapiło wężykowanie, zarówno dla jednego jak i drugiego typu szyn punkty styku kół z szynami przemieszczają się w szerokim zakresie co będzie skutkowało rozłożonym na całe powierzchnie współpracy zużyciem (ściernym i zmęczeniowym) obydwu profili. Ekwiwalentna stożkowatość na szynie 60R2 dla nominalnego prześwitu toru $1435 \mathrm{~mm}$ jest w prawidłowym zakresie $0.09 \div 0.24$ i na szynie S49 jest też w prawidłowym, ale wyższym zakresie $0.09 \div 0.42$.

\subsection{Modification B}

Modification B is to change the R330 radius centers (concave and convex) from $8.25 \mathrm{~mm}$ to $12 \mathrm{~mm}$. This leads to significant differences in the distribution of contact points with respect to the basic profile.

It is characterized by a significantly better operation between the new rail groove 60R2 and good operation with the new S49 rail with a slope of 1:40. If sway occurred, for both the first and the second-type rail, the contact points of the wheels with the rails will move in a wide range which will result in the entire surface in contact and subject to wear (abrasive and fatigue) of both profiles. Equivalent conicity for the rail $60 \mathrm{R} 2$ at the nominal track gauge of $1435 \mathrm{~mm}$ is in the range of 


\subsection{Modyfikacja C}

Modyfikacja C to zmiana środków promieni R330 (wklęsłego i wypukłego) z $8.25 \mathrm{~mm}$ na $16 \mathrm{~mm}$. Jeszcze większe przesunięcie łuku R330 profilu koła powoduje wystapienie bardziej równomiernego rozłożenia nacisków na powierzchni szyny i kole, zwiększenie i stabilizację chwilowej stożkowatości koło-szyna zwiększającą obszar stabilnego obszaru styku w obszarze roboczym i sumaryczne zmniejszenie średniego zużycia kół i toru. Przesunięcie obszaru większego zużycia bliżej obrzeża powoduje zachowanie większej stożkowatości ekwiwalentnej, co powoduje ochronę i mniejsze zużycie samego obrzeża i mniejszy poślizg zmniejszający m.in. prawdopodobieństwo styku dwupunktowego i wystapienia pisków w łukach toru. Jest to spowodowane tym, że wystarczająca stożkowatość również profilu zużytego nie powoduje przeskakiwania punktu styku do obrzeża lub do powierzchni wewnętrznej obrzeża. Na rys. 15 i 16 przedstawiono przebieg stożkowatości ekwiwalentnej, a na rys. $17 \mathrm{i}$ 18 przebieg kontaktu koło-szyna.

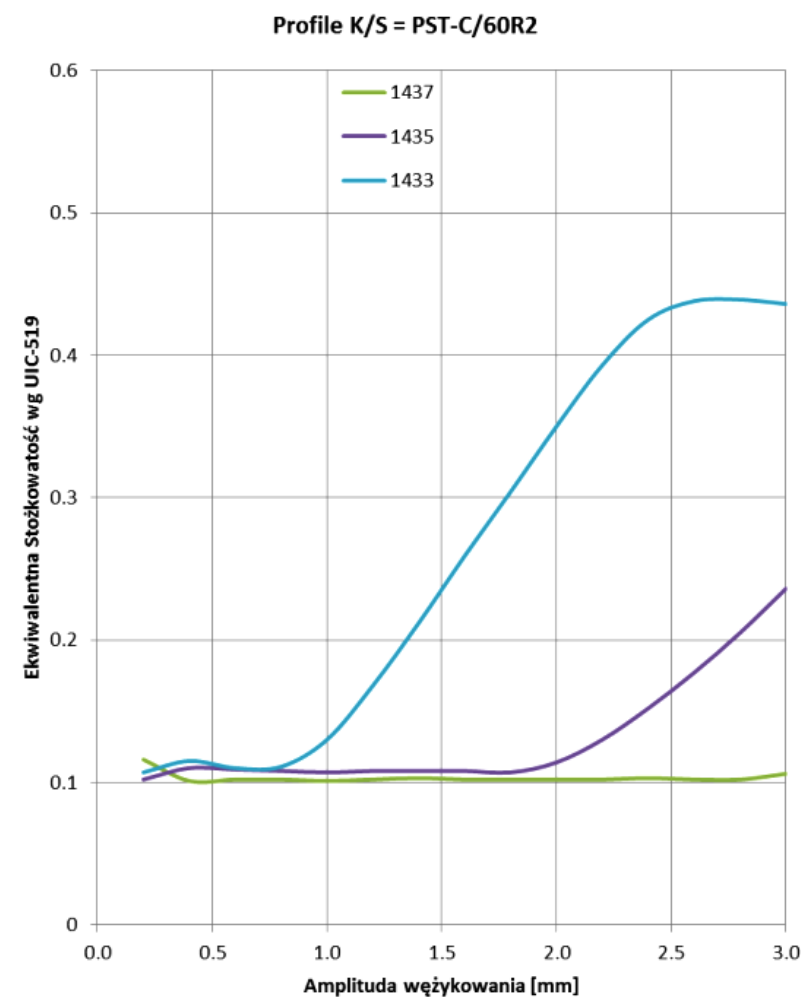

Rys. 15. Stożkowatość ekwiwalentna profilu PST Modyfikacja C - szyna 60R2

Fig. 15. PFT profile equivalent conicity Modification $\mathrm{C}-$ rail $60 \mathrm{R} 2$

\subsection{Modyfikacja Cs}

Modyfikacja polega na zastapieniu promienia R330 (wypukłego) prostą o pochyleniu 1:20 oraz na tym, że zamiast promienia wypukłego R330 pozostawionego w korekcie C zastosowano stożek. Po jej zastosowaniu na torze o szerokości $1435 \mathrm{~mm}$ brak jest zmian w
$0.09 \div 0.24$ and for rail $\mathrm{S} 49$ in a higher, but still acceptable range of $0.09 \div 0.42$.

\subsection{Modification $\mathrm{C}$}

Modification $\mathrm{C}$ is a change of R330 radius centers (concave and convex) from $8.25 \mathrm{~mm}$ to $16 \mathrm{~mm}$. An even greater shift in R330 arc wheel profile results in a more even distribution of pressure on the surface of the rail and wheel, increasing and stabilizing momentary wheel/rail conicity, increasing the area of stable contact zone in the operating range and finally the reduction of the average wheels and track wear. Moving the high wear region closer to the edge allows to maintain a higher equivalent conicity, resulting in protection and less wear on the edges, as well as less slippage, reducing the probability of two-point contact and squeels on curved tracks. This is due to the fact that a sufficient conicity, even for a worn profile, does not lead to contact points moving to the edges or the inner surface of the rim. Figure 15 and 16 shows the changes in equivalent conicity, while in Figure 17 and 18 the changes of wheel/rail contact.

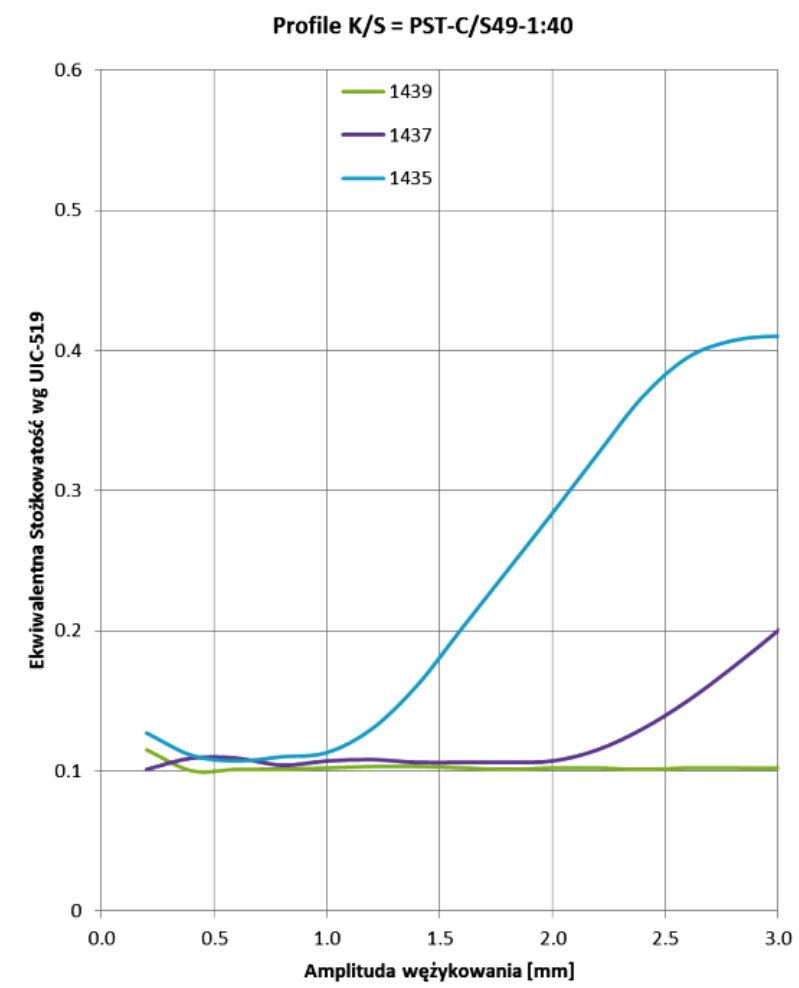

Rys. 16. Stożkowatość ekwiwalentna profilu PST Modyfikacja C - szyna S49 1:40

Fig. 16. PFT profile equivalent conicity Modification C - rail S49 $1: 40$

\subsection{Modification Cs}

The modification consists change of arc radius R330 (convex) to straight line of inclination 1:20 and change of arc radius $\mathrm{R} 330$ left on correction $\mathrm{C}$ to a conical profile.

An application of the modification on a track gauge 
omawianych cechach profili. Przy nieco większym rozstawie szyn winien on wykazywać lepsze prowadzenie dla kół niezależnych. Natomiast dla szerokości toru o szerokościach powyżej 1442mm - punkt styku przemieszcza się bardzo niewiele, co dałoby większe zużycie, ale dla szyn rowkowych niezużytych nadmiernie nie jest to istotne.

Rys. 19 i 20 przedstawiają brak niestabilności w modyfikacji Cs.

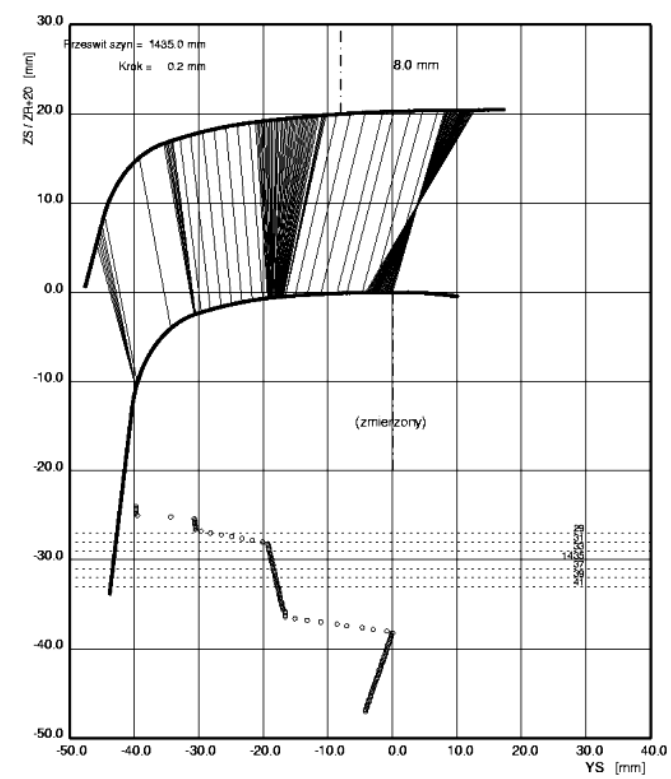

Rys. 17. Rozkład punktów styku profilu PST Modyfikacja C szyna 60R2

Fig. 17. PFT profile contact point distribution Modification C rail $60 \mathrm{R} 2$
$1435 \mathrm{~mm}$ didn't cause any change in profile consider features.

With a little bigger track gauge, guidance of wheels should be better for independent wheels.

For a track gauge $1442 \mathrm{~mm}$ and bigger, the rail-wheel contact point not change significantly lateral position. This cause high level of abrasive wear of normal rails but it doesn't work for grooved tram rails that are little worn.

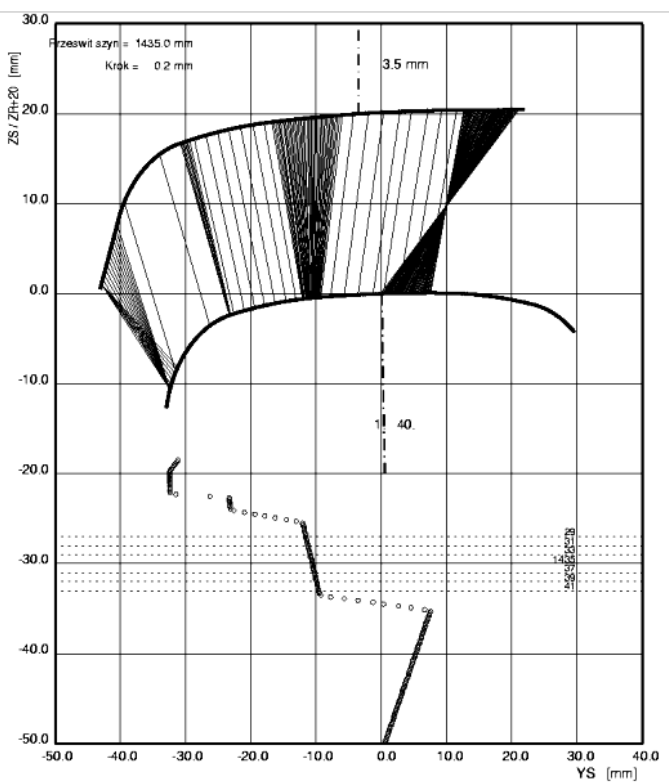

Rys. 18. Rozkład punktów styku profilu PST Modyfikacja C szyna S49 1:40

Fig. 18. PFT profile contact point distribution Modification $\mathrm{C}-$ rail S49 1:40

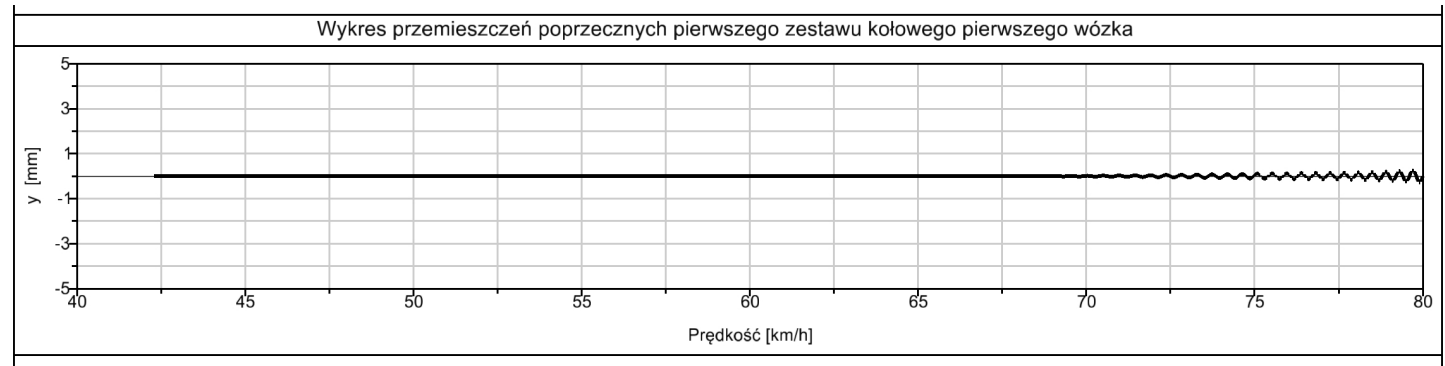

Rys. 19. Stabilność tramwaju z profilem PST Modyfikacja Cs i szyną 60R2 rozstaw $1435 \mathrm{~mm}$

Fig. 19. PFT profile tram stability, Modification Cs and rail 60R2 with gauge $1435 \mathrm{~mm}$

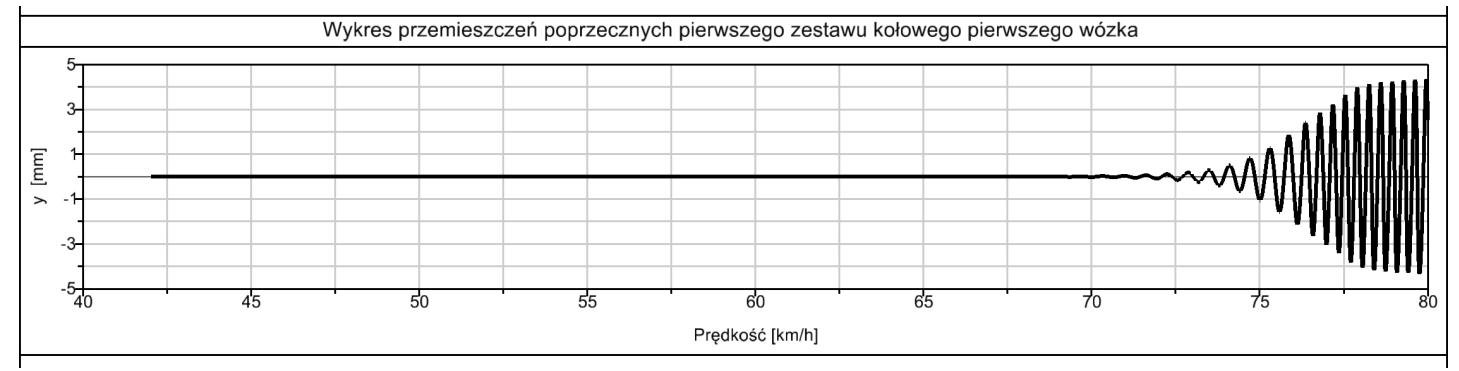

Rys. 20. Przemieszczenia poprzeczne przy profilu koła PST Modyfikacja Cs i szyna S49 1:40 rozstaw $1435 \mathrm{~mm}$

Fig. 20. PFT wheel profile transverse dislocations, Modification Cs and rail S49 1:40 with gauge $1435 \mathrm{~mm}$ 


\section{Podsumowanie}

Zastosowanie jednego ze zmodyfikowanych profili (zwłaszcza modyfikacji C lub Cs) spowodowałoby znaczne uspokojenie poprzecznych przesuwów koła na szynie i w konsekwencji spowodować znaczną poprawę stabilności biegu tramwajów oraz ograniczenie dalszego zużycia. Powinno też w dłuższej eksploatacji powodować stopniowe dostosowywanie zużywania się szyn w kierunku nieco większego, korzystnego pochylnia powierzchni tocznej, również dla szyn częściowo zużytych przed wprowadzeniem modyfikacji. Zarówno dla szyn nowych i zużytych spowoduje to lepsze prowadzenie kół $\mathrm{w}$ torze skutkujące również mniejszym zużyciem bocznym obrzeża i ograniczeniem pisków przy przejeździe przez łuki toru.

Zachowanie tukowego profilu bez odcinka tuku z promieniem $\mathrm{W}$ przeciwną stronę powoduje prawie permanentną nieliniowość profilu $\mathrm{z}$ pochyleniem profilu koła zmniejszającym pochylenie profilu w kierunku zewnętrza profilu, cechę bardzo korzystną dla kół indywidualnych, zapewniająca jedyną dla tych kół stabilność kinematyczną (grawitacyjna). Pozwoliłoby to na uniwersalne zastosowanie jednego profilu dla zestawów kołowych i kół indywidualnych. Korzyść stosowania modyfikacji Cs zamiast $\mathrm{C}$ nie jest znaczna w przypadku profilu szyny $60 \mathrm{R} 2 \mathrm{z}$ powodu ograniczenia zakresu przesuwów poprzecznych koła w tej szynie rowkowej. Maksymalne możliwe przemieszczenia poprzeczne zależą od zużycia profili koła i szyny, co nie było rozpatrywane w tym referacie.

\section{Conclusions}

Using one of the modified profiles (especially the $\mathrm{C}$ or Cs modification) would lead to a significant reduction of lateral sway of the wheels on the rail, and therefore result in a considerable improvement in the stability of tram operation and the reduction of further wear. It should also, in a longer period of time spent in operation, cause gradual adaptation of rail wear towards a slightly larger, beneficial change in the running surface slope, including for tracks that have been partially worn before the introduction of the modification. For both new and used rails this will better movement of the wheels in the track resulting in a slower wear on the side edge and limited squeaks when driving through track bends.

The behavior of the arched profile, without the arc section with radius in the opposite direction, causes the almost permanent profile non-linearity with a wheel profile tilt decreasing the profile inclination towards the outer parts, which is a feature very beneficial to individual wheels, providing the only kinematic (gravitational) wheel stability. This would allow for a universal use one profile for both wheelsets and individual wheels. The advantage of using modification Cs instead of $\mathrm{C}$ is not significant for the 60R2 rail profile due to the limit of the transverse wheel motion in the rail groove. The maximum possible lateral movement is dependent on the level of wear of the wheel and rail profiles, which was not considered in this paper.

\section{Literatura}

\section{Bibliography}

[1] Lang R.: Wyznaczanie optymalnych wymiarów profilów główki szyny tramwajowej oraz profilu bieżni koła tramwajowego. OR 7800, IPS, grudzień 1994.

[2] PN/91 K-88251. Kontur bieżni kół elastycznych wagonów tramwajowych. 1991.

[3] PN-K-92016. Tramwajowe zestawy kołowe elastyczne. Obręcze obrobione. Grudzień 1997.

[4] SIMPACK Release 9.9. SIMPACK GmbH.

[5] Sienicki A.: Rozkład punktów styku profilu koła. Program komputerowy IPS, wersja 2015 r. 